Rosenberg, Morris. 1979. Conceiving the Self. New York: Basic Books. Sarton, George. 1952. A History of Science. Cambridge, MA: Harvard University Press.

Scheff, Thomas J. 1995. "Self-Defense against Verbal Assault: Shame, Anger, and the Social Bond." Family Process 34 (3):271-86.

Seale, Clive. 1995. "Heroic Death." Sociology 29 (4): 597-613.

Skinner, B. F. 1953. Science and Human Behavior. New York: MacMillan. Sokefeld, Martin. 2001. "Reconsidering Identity." ANTHROPOS 96 (2):
527-544.

Somers, Margaret. 1994. "The Narrative Construction of Identity: A Relational and Network Approach." Theory and Society 23 (5): 605-649.

Somers, Margaret and Gloria Gibson. 1994. "Reclaiming the Epistemological "Other': Narrative and the Social Construction of Identity." Pp. 37-99 in Social Theory and the Politico of Identity, edited by CraigJ. Calhoun. Oxford Blackwell.

Srole, Leo. 1978. Mental Health in the Metropolis: The Midtoren Manbattan Study. New York: Harper and Row.

Stapleton, Karyn. 2000. "In Search of the Self: Feminism, Postmodernism and Identity." Feminism and Psychology 10 (4): 463-469.

Steinberg, Marc W. 1999. "The Talk and Back Talk of Collective Action: A Dialogic Analysis of Repertoires of Discourse among NineteenthCentury English Cotton Spinners." American Journal of Sociology 105
(3):736-80.

Stonequist, E. V. 1937. The Marginal Man. New York: Russell and Russell. Stryker, Sheldon. 1989. "Further Developments in Identity Theory: Singularity versus Multiplicity of Self." Pp. 35-57 in Sociological Theories in Progress: New Formulations, edited by Joseph Berger, Morris Zelditch, Jr., and Bo Anderson. Newbury Park, CA: Sage Publications.

Sykes, Gresham M. and David Matza. 1957. "Techniques of Neutralization: A Theory of Delinquency." American Sociological Review 22:66470.

Volosinov, V. N. 1973. Marxism and the Pbilosophy of Language. Translated by L. Matejka and I. R. Titunik. New York: Seminar Press.

Volosinov, V.N. 1987. Freudianism: A Critical Sketch. Translated by I. R. Titunik Bloomington: Indiana University Press.

\section{ANTI-JEWISH PREJUDICE IN CONTEMPORARY Hungary: A SOCIO- Psychological Causal Model}

\author{
BOJAN TODOSIJEVIC AND ZsOLt ENYEDI \\ Central European Unizersity
}

Social Thought E Research, 2002, Vol. 24, 1\&2

Abstract

\begin{abstract}
Predictions from three general approaches toprejudice-personality, social learning and group-conflict-have been examined on a sample of Hun. garian youth and theirparents. The sample consisted of 400 randomly selected collegestudents and their parents from twe Humgarian cities (total $N=800$ ). Thequestionnaireincluded, among others, an antisemitism scale, autboritarianism scale, and sociodemographic variables. Socio-psyy hologicalcausal model reas constructed using unizariate recursize regression graph methodology. The results indicated that students' antisemitism is directly related only topersonality(authoritarianism) and toparents'antisemitism. Students' authoritarianism is related to parents' authoritarianism and familysocioeconomic status as indicated by parents' incomeandeducation). Parents'antisemitism is related to theirowen autboritarian tenden. cies and income, while parents' aut thoritarianism is primarily related to theireducational background. It is concluded that the resultsprimarily support personality approach to prejudiceass represented by Adornoet al.' work (1950), and socialization approach. Group-conflict approach receized ambiguous support in the same way as predictions from this approach conceming individual differencesin prejudiceareambiguous.
\end{abstract}

Key words: antisemitism, prejudice, authoritarianism, socialization.

\section{Introduction}

The roots of modern antisemitism can be traced to the anti-Judaism of the Hellenistic era (cf. Wistrich 1991) and in the identity of early and medieval Christianity (Fein, 1987). But its present form was shaped 
by the intellectual struggles that surrounded the process of emancipation and it reflects the special role Jews played in the $19^{\text {th }}$ and $20^{\text {th }}$ century European societies (Katz 1995; Rürup 1987). Without knowing the nature of theological anti-Judaism or the crises of nationformation and the difficulties of the transformation from a feudal society into a capitalistic one, it is impossible to understand the strength and the character of anti-Jewish prejudices in a country like Hungary. At the same time, in order to explain individual and group differences in the level of antisemitism among citizens of a particular country at a particular time point, one needs a different set of concepts and theories. In this paper, therefore, we attempt to construct a socio-psychological causal model of individual differences in antisemitic prejudice using data on Hungarian adolescents and their parents.

Starting from a socio-psychological point of view, it seems just natural to interpret anti-Jewish attitudes as sub-species of prejudice in general. A principal alternative in the field is to explain differences in susceptibility to prejudice by individual differences in the personality structure. Social learning approach, on the other hand, avoids using psychoanalytic concepts and sees prejudice primarily as learned via socialization. Finally, the main assumption of the group conflict perspective is that prejudice result from conflicts, real or imagined, between groups. The present paper examines causal models of antisemitic prejudices based on the above mentioned three approaches-personality, social learning and group-conflict. In the first part of the paper, we briefly discuss these approaches and derive certain predictions from them. The second part consists of testing these predictions on a sample of Hungarian adolescents and their parents.

\section{Personality Approach}

Literature on personality psychology contains a number of concepts applicable for the explanation of individual differences in prejudice. For example, Eysenck (1954; Eysenck and Wilson 1978) proposed tough-mindedness as a relevant concept, Rokeach (1954) developed a concept of dogmatism, Christie and Geis suggested Machiavellianism (1970), Sidanius and his co-workers elaborated the construct of social dominance orientation (e.g., Sidanius 1993; Pratto et al., 1994). However, in the field of prejudice research, the most widely known and studied is the concept of authoritarianism, originally elaborated by Adorno et al. (1950; see also Stone et al., 1993a; Smith, 1998; Worrell, 1998).

Characteristic for this approach is that it sees prejudices as being rooted in deep psychological, often unconscious, processes. ${ }^{1}$ Adorno et al. found that authoritarian personalities are particularly inclined to accept general ethnocentric and specific antisemitic attitudes. According to this theory, development of the authoritarian character is rooted in family relationships during early childhood. Insistence on strict control of children, on their obedience and respect for rules and regulations, together with the lack of warmth and genuine affection, is seen as instilling authoritarian and anti-democratic tendencies in children. The authors used Freud's psychoanalytic personality theory as their primary theoretical framework. ${ }^{2}$ Hence, they laid emphasis more on concepts like Oedipus complex and defense mechanisms than on learning and conscious motivation. ${ }^{3}$

Concerning the empirical link between authoritarianism and prejudice, including antisemitism, there is an impressive supportive evidence (e.g., for an extensive review see Stone et al., 1993a, particularly Meloen, 1993; see also Kindervater, 1997; Todosijeviæ, 1999b; Scheepers et al., 1990; Billig and Cramer, 1990; Van Ijzendoorn, 1989; Altemeyer, 1988; Rot and Havelka, 1973, Enyedi, 1999). Kindervater (1997), for example, found that different measures of authoritarianism are significantly related to her seven-item antisemitism scale. Antisemitism correlated with 'general authoritarianism' $(\mathrm{r}=.52)$, with 'core authoritarianism' $(\mathrm{r}=.44)$, with 'respect for state authority scale' $(\mathrm{r}=.57)$, but somewhat less with 'authoritarian family structure scale' $(\mathrm{r}=.18)$ (all coefficients $\mathrm{p}<.05$ ). 
Hence, the main general hypothesis derived from this sub-area of the personality approach to prejudice is that authoritarianism significantly predicts antisemitic attitudes. There are many question-marks attached in the literature to the construct validity of the F-scale and the related scales, particularly whether they are measures of personality construct at all (e.g., Rot and Havelka, 1973, Ray, 1990). However, the fact that the F scale stays as a significant predictor of prejudice even after controlling for political, economic and attitude factors, and that it significantly correlates with a number of 'pure' personality scales (e.g., aggressiveness, Todosijevic and Enyedi, 1999), justifies its psychological interpretation.

\section{Social Learning Perspective}

First of all, it should be emphasized that there does not exist the social learning theory of prejudice. Rather socialization and learning are explicitly or implicitly assumed to play crucial role in development of prejudice by various different theories. To illustrate this point, it is possible to list different factors commonly believed to influence prejudice via social learning: experiences in early years of childhood, parents' attitudes and prejudices, influence of peers, teachers, social institutions (like slavery), social contact (hierarchical or egalitarian), mass media representation of minorities, language, tradition, personal experiences, historical and religious factors, ideology (e.g., nationalism), economic factors, etc.

One of the best known explanations of prejudice, the frustrationaggression model (Dollard et al, 1939; Miller and Dollard, 1941), relies heavily on social learning principles. ${ }^{+}$This theory is based on two main assumptions: that frustration leads to aggression (also at the group level), and that aggression can be displaced and directed towards socially defined targets (scape-goats), frequently minorities. Obviously, this theory could be also integrated within the group conflict approach.
Most of the socio-cultural approaches to prejudices, like Katz' and Braly's famous studies $(1933,1935)$, also imply social-learning processes. It is assumed that individuals simply accept prejudiced attitudes because they are widespread in a society, thus disregarding the problem of individual differences within examined groups or society in general.

Explanations of prejudice which stress the role of tradition and social circumstances also imply social learning. It has been argued that where prejudices are more legitimate part of value system they are transmitted through social conditioning and authoritarian personality plays smaller role (so called 'normative pressure' hypothesis, cf. Heaven, 1984, Pettigrew, 1959).

The general hypothesis following from social learning perspective is that those who are exposed to prejudice will tend to learn them. The most straightforward specific derivation is that there should exist positive correlation between prejudices of parents and of their children, regardless of personality structure of persons involved in learning process.

\section{Group-Conflict Approach}

Further from individual psychology are theories which emphasize conflicts between groups as the primary source of prejudices (e.g., Brown, 1995). A body of experimental evidence suggests that not only conflicts between groups but even the very existence of groups is sufficient to produce prejudices and differential treatment of inand out-groups. Famous illustrations of this approach are experiments using the so called Minimal Group Paradigm (e.g., Tajfel, 1981; Tajfel et al., 1971) and the Realistic Group Conflict Theory (e.g., Sheriff, 1966).

Group conflict theories can considerably differ in their focus and level of conflicts they consider. Some of the classical topics in this area are, for example, problems of whether social mobility of 
one group is sometimes leading to increased prejudices due to increased inter-groups tension (e.g., Silberstein and Seeman, 1988), or whether and what kind of contact between groups can diminish prejudices (e.g., Weiss, 1988, Hamberger and Hewstone, 1997). Even outside of social psychology many authors attribute the causal role in certain prejudices to group conflicts. For example, Bibó (1991) elaborating the role of cultural and historical processes in contemporary antisemitism in Hungary, analyses group conflicts between Jews and Gentiles.

An example of the use of group membership as essential for explaining prejudice and stereotypes is research by Triandis and Triandis. $(1988)^{5}$. In their view, prejudices are partly results of attempts to solve cognitive dissonance concerning existing social inequalities. In case of Jews in the USA, above-average socio-economic status of Jews is explained through stereotyping them as being "pushy, shrewd, grasping, intelligent, sly and aggressive” (p. 513).

In the case of contemporary Hungary, it is not obvious to which groups the approximately 100.000 Hungarian Jews are an important conflicting group, whether objectively or symbolically. Group conflicts relevant for antisemitic attitudes could be based obviously on different grounds, as they have been during the history. In the middle ages, for example, antisemitism was based primarily on religious grounds, while with the emergence of nationalist doctrine it became based on racial doctrine (e.g., Wistrich, 1992). Hence, it seems that the group-conflict approach does not provide us with straightforward relevant testable hypotheses, besides obvious ones, like that Jews should, on average, be less antisemitic than Gentiles.

Group conflict theories are naturally more concerned with group differences in prejudice than with individual variations within groups, so predictions for the individual-level analysis are not obvious. Perhaps, social identity theory could predict that those sensitive to the threat to their group identity would be more susceptible to prejudice-a hypothesis that could bridge the gap between authoritarianism and Social Identity theories. However, the literature is more focused on inter-groups relationships, and generally on groups that are easily identifiable, like ethnic or socio-economic groups. Hence, we hypothesize that antisemitic prejudice in Hungary will depend on socioeconomic group-membership (cf. Kovács, 1996).

\section{The Theoretical Model}

Attempts to simultaneously test several predictions from various theories are rare in the literature. Partly it is because of the complexity of the theories of prejudice. It is difficult to successfully operationalize even some of the most relevant aspects of a single theory, let alone several theories at the same time. Another important reason for the deficiency of simultaneous comparisons is the difficulty in specifying unambiguous and/or testable predictions. Furthermore, it is possible to derive same predictions from different theories, thus making differential evaluation of theories rather difficult.

The goal of the present paper is to compare the explanatory power of above referred theories on antisemitic attitudes in Hungary. The goal is by no means to offer decisive arguments pro or contra these theories, because for that purpose much more complex research design would be needed.

On the basis of theoretical considerations, the variables included in this research are ordered in the way presented in Figure 1.

Figure 1 Order of variables

\begin{tabular}{|c|c|c|c|}
\hline $\begin{array}{c}\text { Antisemitic } \\
\text { attitude }\end{array}$ & $\begin{array}{c}\text { Authoritar- } \\
\text { ianism } \\
\text { AS }\end{array}$ & $\begin{array}{c}\text { Parent's } \\
\text { antisemitism } \\
\text { PAS }\end{array}$ & $\begin{array}{c}\text { Parent's } \\
\text { Authoritar- } \\
\text { ianism } \\
\text { PAUT }\end{array}$ \\
$\begin{array}{c}\text { Socio- } \\
\text { Economic } \\
\text { status } \\
\text { Income } \\
\text { Education }\end{array}$ \\
\hline
\end{tabular}

Note: the causal chain goes from the right to the left. 
AS is treated as a response variable of primary interest. According to Adorno et al's (1950) theory, authoritarianism could be treated as the principal causal factor behind individual differences in antisemitism. Therefore, AUT variable is immediately behind the primary response variable. Parents' antisemitism (PAS) is explanatory to children's authoritarianism and directly or indirectly to children's antisemitism. Social learning theories would predict that the effect of authoritarianism diminishes after controlling for direct socialization, i.e., PAS. Parents' authoritarianism is seen as potentially influencing PAS, AUT and AS, while not being under their influence. One could argue that PAS and PAUT should be analyzed as variables on equal footing, since both are attitudinal variables and the potential influence between them could go in both directions. However, relying on Adorno et al's theory, authoritarianism should be seen as 'psychologically deeper' variable whose surface manifestation is antisemitism. Also, in this view, the development of authoritarianism precedes the development of antisemitism.

Parents' income and education are treated as final explanatory variables. They are presented as being on equal footing. While this is problematic since education usually antedates income, for the children's antisemitism this distinction is not particularly important. Furthermore, placing Income in front of Education would not change anything substantively in the performed analysis.

\section{Hypotheses}

From the three described theoretical approaches to prejudice, certain predictions or hypotheses could be derived concerning the included variables. It is, however, important to note that these predictions are rather tentative and, particularly in the case of group conflict theories, even disputable derivations. Therefore, it is more appropriate to understand the following analysis as descriptive or exploratory than as confirmatory in the strict sense. Nevertheless, the following main general hypotheses are derived from the three approaches to prejudices:

$<$ Authoritarianism theory predicts that personality, i.e., authoritarianism, has a primary role in antisemitic attitudes (both for parents and children) and that other variables can have only indirect influence.

Social learning theories would predict that parents' attitudes are much more important than any other variable.

$<$ From the group conflict approach predictions are rather ambiguous. One hypothesis could be that educational level should be positively related to antisemitism, since Jews tend to concentrate in middle-class occupations, especially where university education is required (cf. Kovács, 1996). Similar hypothesis could be proposed for the Income variable. On the other hand, groups of lower education and income could perceive Jews as unjustly superior to them and therefore express prejudiced attitudes toward them (cf. Triandis and Triandis, 1988). ${ }^{6}$

\section{Method}

\section{Sample}

The study is based on a random sample of 400 adolescents, aged 1617 , and their parents. One parent of every adolescent respondent was interviewed, so the total sample included 800 respondents. $22.8 \%$ of parents were of the female gender, while sexes were more equally represented among the children: $48.5 \%$ of them were girls. Median age of the children was $16(83.5 \%$ were born in 1981 , the rest in 1980). Average age of the parents was 44 years, with standard deviation of 5 years and six months.

The study was conducted in November and December of 1997, in two Hungarian cities, Sopron and Salgótarján. The first is a prosperous, tourist city in the West, while the other one is a working class town in the North, with an especially high unem- 
ployment rate. Equal number of interviews was collected in both cities. Preliminary analysis showed that causal models constructed separately for the two towns do not essentially differ, so we present results on the basis of the total sample.

\section{Variables}

The following variables are included in the model:

1. AS-Antisemitic attitudes or prejudice of the children. This is the response variable of the primary interest in this study. Sample item: There is a secret Jewish co-operation in which determines the political andeconomicprocesses.

2. This variable is constructed as the first principal component from the Antisemitism scale, consisting of 13 items in Likert form with 4 degrees of dis/agreement. Answer option of 'do not know' was assigned intermediate value (1 stands for 'strongly disagree', 4 for 'strongly agree', while 'do not know' received the value of 2.5; the same strategy was applied to both samples and to both Antisemitism and Authoritarianism scales). Reliability of the Antisemitism scale (Cronbach's alpha) on the sample of the youth is .78 .

The entire AS scale is given in Table 1, with both samples' means on all items. Basic results of the principal component analysis are also given in the Appendix (Table 1).

2. AUT-Children's Authoritarianism, defined as the first principal component of the 21-item scale of the same format as the AS scale. The AUT scale is based on the Adorno et al.'s F scale and Altemeyer's RWA scale (Altemeyer, 1981, 1988). Sample item: The most important virtues a child has to learn are obedience and respect of authorities.

Four items from the entire 25-item scale are omitted for they explicitly dealt with relationship of Hungarians and ethnic mi- norities. Presence of such items would artificially increase relationships due to the overlapping content. Alpha reliability of the AUT scale on the youth sample is .68.

Entire AUT scale and basic results of principal component analysis is given in the Appendix (Table 2).

3. PAS-Parents' antisemitism is constructed in the same way as the children's antisemitism (AS). Reliability of this scale on the sample of parents is .78 .

4. PAUT-Parents' authoritarianism is constructed in the same way as the AUT scores for the children. Reliability of the AUT scale on the sample of parents is .78 .

5. Income-this variable consists of parents' answer to the question concerning net family income per month.

6. Education-this is a composite variable, constructed by adding answers to two questions dealing with educational level of both parents. The questions had 7 categories, from category 1 meaning unfinished primary school, to 7 meaning university education. Hence, the composite variable had a minimum of 2 and a maximum of 14. Frequency tables of these two items are given in the Appendix, tables 3 and 4. Preliminary analysis showed that such a joint variable has better predictive power than educational level of a single parent.

\section{Results and discussion}

\section{Antisemitism of the youth and of their parents}

Before presenting the main results, it is interesting to take a view of some indicators of the extent of anti-Jewish attitudes among the youth and their parents. Table 1 presents arithmetic means of the children and parents on the AS items. It appears that parents generally displayed lower level of antisemitic attitudes than 
their children. For example, to the item I: It would be better if Jews lived in their own state, Israel, children expressed higher agreement. They agreed or strongly agreed in $32,9 \%$ of cases, while parents expressed such agreement in $15.7 \%$ of cases. This facts seems to contradict the widely held belief that prejudices are decreasing over time. However, it is possible that these results represent the age effect and not cohort or period effects. On the other side, parents seem to be more inclined towards belief in Jewish conspiracy-they have higher means on the respective items ( $\mathrm{B}$ and $\mathrm{E}$ ).

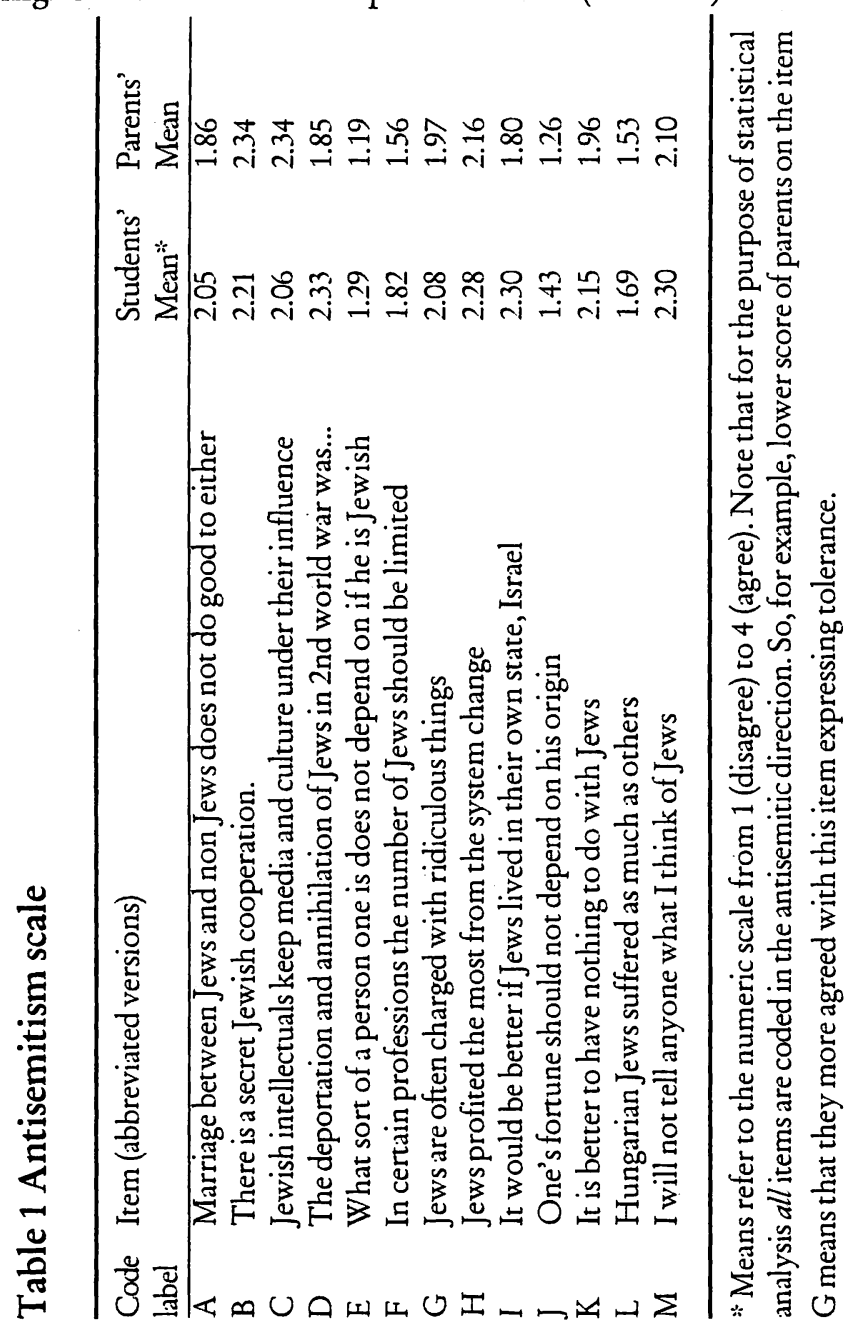

Another view on the same problem of intergenerational differences in ethnic prejudice is provided by the general positive or negative attitude towards different ethnic groups. Differences between the youth and their parents in their general evaluation of nine ethnic and national groups are presented in the Table 2.

Table 2 Mean answers of the adolescents and parents to the question "How likable do you find..." certain ethnic group

\begin{tabular}{lcc}
\hline Ethnic group & Parents & Adolescents \\
\hline Gypsies & 2.72 & 2.37 \\
Rumanians & 2.96 & 2.74 \\
Slovaks & 3.15 & 2.98 \\
Blacks & 3.34 & 3.58 \\
Chinese & 3.48 & 3.25 \\
Austrians & 3.63 & 3.36 \\
Jews & 3.66 & 3.13 \\
Polish & 4.08 & 3.24 \\
\hline
\end{tabular}

Note: Answer options are from 1-very antipathetic, to 5-very sympathetic.

These results again show that children tend to express more prejudiced views: their mean evaluations are lower than that of parents for all groups except for Blacks. However, considerable similarity exists between the relative evaluation of different groups. Both parents and children expressed the most negative view of Gypsies, then Rumanians and Slovaks. Chinese, Austrians, Poles and Jews are evaluated more positively.

These findings could be discussed extensively, but here they serve only to illustrate the importance of studying antisemitic attitudes in Hungary. While it appears that Jews are relatively favorably viewed by the respondents comparing to other groups, it is worrying that the evaluation of Jews shifted downward among the children. Inhibitions of the older generations seem not to function with the youth, even though, or exactly because, their socialization took place in a more democratic environment. 


\section{Constructing the Causal Model}

A causal model including the six examined variables was constructed via a series of regression equations, starting from the primary response variable, i.e. children's antisemitism. Each variable was regressed on all the other variables on its right side. The main results of the performed regression analyses are presented in the Table 3. Accepted level of statistical significance is $\mathrm{p}<.05$.

The final results are presented in the form of univariate recursive regression graph ${ }^{7}$, as presented in the Figure 2. The graph is constructed roughly following the rules elaborated by Cox and Wermuth (1996). ${ }^{8}$

Figure 2 Empirical model obtained in this study: univariate recursive regression graph

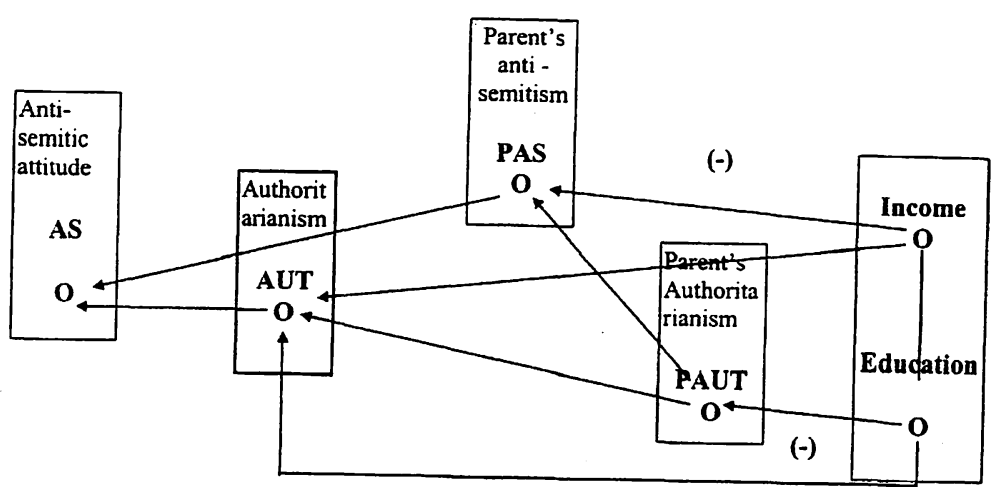

$(-)$

Presence of an arrow (directed edge) denotes a significant conditional relationship between a variable towards which the arrow is directed and a variable from which the arrow starts, controlling for all other variables to the right of the pointed variable. This means, for example, that when $\mathrm{AS}$ is regressed on all the other variables simultaneously, it is significantly related only to AUT and PAS.
Table 3 Summary of regression equations for the causal model of antisemitism. Variables at the top of the columns are regressed on the variables in the rows. In the lower part of the table are given standardized regression coefficients (beta).

\begin{tabular}{|c|c|c|c|c|c|}
\hline & AS & AUT & PAS & PAUT & INCOME \\
\hline $\mathrm{R}$ & .49 & .46 & .43 & .44 & .23 \\
\hline $\mathrm{R}^{2}($ F-test $)$ & $.24(* * *)$ & $.21(* \cdots * \cdots)$ & $.19(\cdots)$ & $.19(\because * \%)$ & 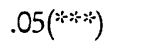 \\
\hline \multicolumn{6}{|l|}{ Beta coefficients } \\
\hline AUT & $.33 \cdots *$ & & & & \\
\hline $\mathrm{PAS}^{\mathrm{a}}$ & $.34 \div \div \%$ & .05 & & & \\
\hline PAUT & -.10 & $.27 \div \div \%$ & $.42 * \% \%$ & & \\
\hline INCOME & .10 & $.15^{* *}$ & $-.13 *$ & -.03 & \\
\hline EDUC & -.05 & $-.26 \% * \%$ & .05 & $-.43 \% * \%$ & .23 \\
\hline
\end{tabular}

${ }^{n+*} \mathrm{p}<.001 ; \mathrm{p}<<.01 ; \mathrm{p}<.05$

"Prefix $\mathrm{P}$ in front of variable labels refers to the sample of parents. E.g., PAS denotes parents' antisemitism.

The results indicate that children's AS is under the direct influence only of authoritarianism (personality) and the parents' antisemitic attitudes (socialization). It suggests that both authoritarianism theory and socialization theory capture parts of the processes underlying the development of antisemitic attitudes. It is interesting to note that standardized coefficients for these two direct explanatory variables of AS are virtually equal (beta's are .33 and .34 respectively).

Social background variables, according to this model, have only indirect influence on the AS attitudes (no directed edge between AS and Income and Education). Income's power is on the border of statistical significance $(p=.06)$, and under listwise deletion of missing vales the relationship is statistically significant $(p=.05)$. The relationship is weak (beta $=.11$ in listwise condition), but the most interesting is the direction of the relationship. Most studies report negative relationship between income or some other indicator of the socio-economic status and prejudice. But, according to our findings, the children of the better off (but not necessarily educated) groups turn more, and not less antisemitic. 
Our tentative explanation is that the children of these upwardly mobile groups might develop an inferiority complex against the traditional, i.e. "Jewish", intellectual elite. Interpreting the difference in this way, we might also give some justification to the group-conflict model.

Children's authoritarianism (AUT) is directly related to authoritarianism of parents (PAUT) (beta $=.27)$, and to socio-economic status as indicated by Income $($ Beta $=.15)$ and Education (Beta $=-.26)$ variables. Relationship between AUT and PAUT is supportive of the authoritarianism theory in the sense of the hypothesis that authoritarian parents "breed" authoritarian children. Also, those inclined to believe in (partial) genetic determination of personality traits could interpret this result as supportive of their views.

Relationship of AUT with Income and Education suggests that intra-family processes are not sufficient to explain authoritarianism phenomenon and that broader social factors have to be taken into account. While negative relationship between AUT and Education has been expected (cf. Scheepers et al., 1990, Schuman, Bobo, and Krysan, 1992), it is surprising that AUT and Income are positively related. It contradicts the usual claims and the famous Lipset thesis (1959) that poorer classes are more authoritarian. If this is not an artifact result (coefficients are low, though significant), it could be interpreted with reference to group conflict theories and the hypothesis that social mobility, regardless whether up- or down-ward increases psychological tension and is expressed in increased intolerance. It is also consistent with the interpretation that higher income brings one into the social stratum which is more interested in preserving the existing social order. On the other hand, it is not clear why this is not expressed also in connection with the parents' authoritarianism. It is possible that children of better-off parents tend to be more status-conscious anticipating the competition with various out-groups, and therefore more authoritarian. ${ }^{9}$ On the other hand, parents with higher income could feel already securely settled in their social position and therefore, controlling for Education, feel less group competition pressure.
In any way, it is important to note that authoritarianism (AUT) is the most important intervening variable between AS and other variables (primarily socio-economic background). This confirms similar findings by Scheepers et al. (1990).

PAS is under the direct influence of PAUT and Income. The former relationship is again in accordance with Adorno et al's theory (beta coefficient is .42), while the relationship PAUT-Income (Beta=-.13) suggests that frustration-aggression theory also can contribute to understanding of the antisemitic attitudes.

PAUT is related directly to Education but not to Income. This finding is in accordance with similar results reported in literature. Namely, Lipset's thesis on working-class authoritarianism is usually contested by findings that authoritarianism is related only to education, but not to other indicators of social class (e.g., Dekker and Ester, 1993). This can be explained in different ways. For example, it is possible that education in itself decreases authoritarianism by developing tolerant and pro-democratic attitudes. More cynical explanation would be that the better educated are more aware of what answers are socially desirable and therefore pretend to be more tolerant than they really are.

An unexpected finding is that although parents' education is related to authoritarianism as has been expected, it was not related to the antisemitic attitudes of neither children nor parents. One possible reason for that could be that this relationship in nonlinear. Kovács (1996) found "U" shape frequency distribution of antisemitism and education of parents. Below and above average educated families' offspring were more antisemitic. It may be the reason why here no direct relationship between parents' education and AS and PAS was found. However, present data do not confirm his findings. Although conditional relationships are insignificant, as can be seen from regression equations and the Figure 2, marginal relationships are significant and negative (see covariance matrix in the Table 4). Moreover, data in the Appendix, Table 5, show negative and quite obviously linear relation- 
ship between parents' educational level and their and their children's antisemitism.

Kovács also found higher antisemitism among more propertied families (1996). Similarly, concentration matrix (partial coefficients) in Table 4 shows a weak positive relationship between Income and children's antisemitism (though not zero-order relationship). However, income and parents' antisemitism are negatively related. Obviously, these relationships are still unclear and unreliable and further more elaborated research is needed to clarify them.

Table 4 Concentration (above diagonal) and covariance (below diagonal) matrixes, and variances (diagonal) ${ }^{a}$. Independencies $(p>.05)$ are given in boldface letters.

\begin{tabular}{|c|c|c|c|c|c|c|}
\hline & AS & AUT & PAS & PAUT & INCOME & EDUC \\
\hline AS & $1.00^{\circ}$ & $.32^{m / n}$ & $.33^{\text {kit }}$ & -.09 & $.11^{\mathrm{b}}$ & -.04 \\
\hline AUT & $.37^{3 *}$ & 1.00 & -.06 & $.26^{*+1}$ & $.12^{*}$ & $-.22^{-n}$ \\
\hline PAS & $.35^{* / 5}$ & $.18^{* * 4}$ & 1.00 & $.37^{n+3}$ & $-.17^{* * 1}$ & .08 \\
\hline PAUT & $.18^{* n}$ & $.39^{n+m}$ & $.41^{* * *}$ & 1.00 &. .01 & $-.33^{n+t}$ \\
\hline INCOME & .06 & .05 & $-.17^{k n}$ & $-.13^{n+1}$ & $22.53^{d}$ & $.23^{m \infty}$ \\
\hline EDUC & $-.15^{* * n}$ & $-.35^{* 8}$ & $-.15^{* n}$ & $-.44^{3+x}$ & $.23^{* * n}$ & 4.92 \\
\hline
\end{tabular}

a Covariance matrix consists of zero-order correlation coefficients; Concentration matrix consists of partial correlation coefficients, controlling for all other variables except the analyzed pair. Coefficients are calculated using pairwise treatment of missing values. Hence, the coefficients are based on different subsets of cases.

$\mathrm{b}$ This coefficient is on the border of statistical significance (e.g., $\mathrm{p}=.062$, pairwise).

c Variance of standardized and normalized factor scores are, of course, equal to 1.

${ }^{d}$ Values of this variable are all divided by a constant, therefore the small size of variance.

$\mathrm{p}<.01 ; \mathrm{p}<.05$

Referring back to the discussed three approaches to antisemitism and prejudice in general, is seems that a single general theory is not likely to be sufficient. One of the reasons is that prejudices are multifunctional (e.g., Rot, 1989). They can perform different functions for different individuals and groups, and different functions simultaneously for the same individual. In the presented causal model, which is obviously simplified and incomplete, different theories and concepts were needed to interpret the established relationships. The results suggest the need for integration of different approaches.

In fact, as has already been mentioned, most accounts of prejudice tend to incorporate elements of several basic perspectives. Personality and group conflict approaches imply social learning processes in the development of prejudice. Ultimately, the only explanation of prejudice really alternative to social learning perspective would be genetic determinism. Therefore, the three examined theories should be seen more as complementary than exclusive ones. For example, it has been argued that group approach and authoritarianism could be integrated (Stone et al., 1993b, p. 238; Duckitt, 1989). Altemeyer's extensive studies (e.g., 1981, 1988) show that it is fruitful to combine the ideas of authoritarianism research and social learning approach. Stone (1993) also points toward integration of cognitive, psychodynamic and other approaches to authoritarianism and prejudice.

The main suggestions from the present, primarily explorative study are that antisemitic attitudes are partly directly transferred from parents to their children via socialization, and that personality (authoritarianism) mediates the influence of other factors including socio-economic variables.

\section{Conclusions}

The most important results of the performed analysis could be summarized in the following way:

1. Predictions of both personality and social learning theories are generally verified. Antisemitic attitudes are independently related to authoritarianism and parents' attitudes in approximately equal degree. 
2. Authoritarianism theory received particularly strong support in the sense that authoritarianism appears to be the most important explanatory variable both for children's and parents' antisemitic attitudes.

3. Authoritarianism of parents and children is primarily influenced by (parents') educational level. This is potentially problematic for the original authoritarianism theory. If authoritarianism proves to be just an expression of lower educational level than the conception of it as a deep personality trait might be justly criticized (cf. Schuman, Bobo and Krysan, 1992). The problem is further complicated by the possibility that authoritarianism scales could be considerably influenced by conscious dissimulation.

4. Group-conflict theories received ambiguous support, in the same way as hypotheses derived from them were ambiguous. At the same time, the results indicated that social mobility may lead to increased antisemitism.

5. The analyzed three approaches to prejudices seem to be all relevant for understanding the phenomenon in question. Therefore, they should be conceived as complementary theories rather than exclusive ones.

\section{Notes}

"An earlier version of the paper was presented at the $14^{\text {th }}$ World Congress of Sociology, Montreal, July 1998.

'This is the most widely held view of the Adorno et al's contribution (e.g., Brown, 1995). It is rather simplistic view, but it is out of the scope of this paper to discuss the issue more extensively (cf. Todosijeviæ, 1999a). For recent discussion of different aspects of the authoritarianism research see the volume by Stone et al., 1993a, and the special issue of Social Thought and Research, 1998, Vol.21.

'Sometimes authoritarianism theory is presented as an example of frustration-aggression, 'displacement' or scape-goat theories (e.g., Brown, 1995). Adorno et al. explicitly rejected this view (1982, p. 163).
${ }^{3}$ Alternative conceptualizations of authoritarianism have also been developed. Altemeyer $(1981,1988)$, for example, based his theory primarily on social learning perspective rather then on psychoanalysis.

+ The earlier version of the theory (1939) was related to psychoanalysis, but in the later version (1941) the role of learning was more emphasized.

'The main variables they are dealing with are race, social class, religion, and nationality - all indicators of group membership.

${ }^{6}$ Religiosity could have been also used as a variable potentially indicative of group-tension. This is because of the age-old cleavage between Christianity and Jews (cf. Wistrich, 1992). However, the variables indicating the degree of religiosity, churchattendance, or denomination (of parents or of children) had no significant relationship with the included variables in our data. Therefore these variables have been omitted from the model.

${ }^{7}$ In fact, due to the two variables in the box of socio-economic variables connected with an undirected edge, this model should be better labeled as Partially di. rected acyclic graph (Cox and Wermuth, 1996, p. 34). However, in the present analysis nothing significant would change if the arrow would be directed from Education to Income.

${ }^{8}$ Because the adopted methodological approach can incorporate simultaneously variables on different level of measurement, there are no numbers above the arrows as is the case with path analysis.

${ }^{9}$ The in-group bias of authoritarians might have an adaptive function in groupcompetition situations, increasing group solidarity and preventing out-groups success.

\section{References}

Adorno, T.W., Frenkel-Brunswik E., Levinson, D. J. and Sanford, R. N. (1950). The Autboritarian Personality, Harper and Row, New York. Abridged edition: 1982, Norton \& Company, New York, London.

Altemeyer, B. (1981). Right-wing authoritarianism. Winnipeg, University of Manitoba Press.

Altemeyer, B. (1988). Enemies of Freedom: Understanding Right-Wing Authoritarianism. Jossey-Bass Publishers, San Francisco, CA.

Bibó, I. (1991). The Jewish Question in Hungary After 1944. In K. Nagy (ed.) (1991), Istran Bibó: Democracy, revolution, self-determination. Selected weritings. Columbia University Press, NY.

Billig, M. and Cramer, D. (1990). Authoritarianism and Demographic Variables as Predictors of Racial Attitudes in Britain. New Community, 16, 2, 199 211.

Brown, R. (1995). Prejudice: Its Social Psychology. Blackwell, Oxford, UK.

Christie, R. and Geis, F. (1970). Studies in Machiavellism. Academic Press, New York. 
Cox, D.R. and Wermuth, N. (1996). Multivariate Dependencies. Chapman \& Hall, London.

Dekker, P. and Ester, P. (1993). Authoritarianism and socio-economic differentiation: the Lipset thesis. In P. Dekker and P. Ester, Social and Political Attitudes in Dutch Society: Theoretical Perspectives and Survey Evidence. Social and Cultural Studies, Vol.16, SCP, Rijswijk.

Dollard, J., Doob, L.W., Miller, N.E., Mowrer, O.K. and Sears R.R. (1939) Frustration and Aggression. Yale University Press, New Heaven, Conn.

Duckitt, J. (1989). Authoritarianism and group identification: A new view of an old construct. Political Psychology, 10, 63-84.

Eysenck, H. J. (1954). Psychology' of Politics. Routlege and Kegan, London.

Eysenck, H. J. \& Wilson, G. D. (Eds.) (1978). The Psychological Basis of Ideology. MTP Press Ltd. Lancaster.

Fein, H., (1987). Explanations of the Origin and Evolution of Antisemitism. In H. Fein (ed.), The Persiting Question. Sociological Perspectives and Social Contexts of Modern Antisemitism (pp. 3-23). Berlin-New York: Walter de Gruyter.

Hamberger, J. and Hewstone, M. (1997). Inter-ethnic contact as a predictor of blatant and subtle prejudice: Tests of a model in four West European nations. British Journal of Social Psychology, 36, p.173-190.

Heaven, P.C.L. (1984). Afrikaaner Patriotism Today: The Role of Attitudes and Personality. Canadian Review of Studies in Nationalism, 11, 1, 133-139.

Katz, J. (1980). From Prejudice to Destruction: Antisemitism 1770-1933, Cambridge, Mass. Cambridge University Press.

Katz, D. and Braly, K. W. (1933). Racial Stereotypes of 100 College Students. Journal of Abnormal and Social Psychology, 30, 280-190.

Katz, D. and Braly, K. W. (1935). Racial Prejudice and Racial Stereotypes. Journal of Social Psychology, 30, 175-193.

Kindervater, A. (1997). Measuring Antisemitism: An Example of Austrian Youtb in 1992. Paper presented at the XX Annual Scientific Meeting of the ISPP, Krakow, Poland, July 1997.

Kovács, A. (1996). Anti-Semitism and the Young Elite in Hungary. Sociological Papers, Vol. 5., No. 3. Sociological Institute for Community Studies, Bar-Ilan University, Jerusalem.

Lipset, S. M. (1959). Democracy and working-class authoritarianism. American Sociological Review, 24, 482-502.

Meloen, J.D. (1993). The F Scale as a Predictor of Fascism: An Overview of 40 Years of Authoritarianism Research. In Stone et al., 1993a.

Miller, N. E. and Dollard, J. (1941). Social Learning and Imitation. New Haven: Yale University Press, Oxford University Press.

Pettigrew, T.F. (1959). Regional Differences in Anti-Negro Prejudices. Journal of Abnormal and Social Psychology, 59, 1, 28-36.

Pratto, F., Sidanius, J., Stallworth, L. M. \& Malle, B. F. (1994). Social Dominance Orientation: A personality variable relevant to social roles and intergroup relations. Joumal of Personality and Social Psychology, 67, 4,741-763.
Ray, J. J. (1990). The Old-Fashioned Personality. Human-Relations, 43, 10, 997-1013.

Rokeach, M. (1954). The Nature and Meaning of Dogmatism. Psychological Review, 61, 194-204.

Rot, N. (1989). Osnovi Socijalne Psibologije. [Foundations of Social Psychology]. ZUNS Beograd.

Rot, N. and Havelka N. (1973). Nacionalna vezanost i vrednosti kod srednjoskolske omladine. [National Attachment and Values in High-School Youth]. Institut za psihologiju, Beograd.

Rürup, R. (1987). Emanzipation und Antisemitismus. Studien zur "Tudenfrage" der bürgerlichen Gesellschaft. Franfurt: Taschenbuch Verlag.

Scheepers, P., Felling, A., Peters, J. (1990). Social Conditions, authoritarianism and Ethnocentrism: A theoretical model of the early Frankfurt School updated and tested. European Sociological Review, 6, 1, 15-26.

Schuman, H., Bobo, L. and Krysan, M. (1992). Authoritarianism in the General Population: The Education Interaction Hypothesis. Soc. Psychology Quarterly, 55, 4, 379-387.

Sidanius, J. (1993). The psychology of group conflictand the dynamics od oppression: A social dominance perspective. In S. Iyengar, and W. McGuire (Eds.), Explorations in Political Psychology (pp. 183-219). Durham, NC: Duke University Press.

Silberstein and Seeman (1988). Social Mobility and Prejudice. In W. Bergman (ed.), Error Without Trial. Psychological Research on Antisemitism (pp. 258-271). Walter de Gruyter, Berlin, New York.

Sherif, M. (1966). Group Conflict and Co-operation: Their social psychology. Routledge and Kegan Paul, London.

Smith, D.N. (1998). The Ambivalent Worker: Max Weber, Critical Theory and the Antinomies of Authority. Social Thought and Research, 21, 1-2, 35-83.

Stone, W.F. (1993). Psychodynamics, Cognitive Functioning, or Group Orientation: Research and Theory in the 1980s. In Stone et al., 1993a, pp. 159-181.

Stone, W.F., Lederer, G. and Christie, R. (Eds.) (1993a). Strength and Weakness: The Authoritarian Personality Today. Springer-Verlag, New York.

Stone, W.F., Lederer, G. and Christie, R. (1993b). The Status of Authoritarianism. In Stone et al., 1993a, pp. 229-245.

Tajfel, H. (1981). Human Groups and Social Categories. Cambridge University Press, Cambridge.

Tajfel, H., Flament, C., Billig, M.G. and Bundy, R.P. (1971). Social categorization and intergroup behaviour. European Journal of Social Psychology, 1, 149-178.

Todosijeviæ, B. (1999a). Az autoriter személyiség: az elõitéletesség pszichoanalízise. [The Authoritarian Personality: Psychoanalysis of the Prejudiced]. In: A. Kovács (Ed.), Modern Antiszemitizmus (pp. 242-272). Budapest: Új Mandátum.

Todosijeviæ, B. (1999b). Relationship Between Authoritarianism and Nationalist Attitudes. In Zs. Enyedi and F. Erõs (Eds.), Authoritarianism and Prejudice: Central European Perspectives (pp. 54-88). Budapest: Osiris. 


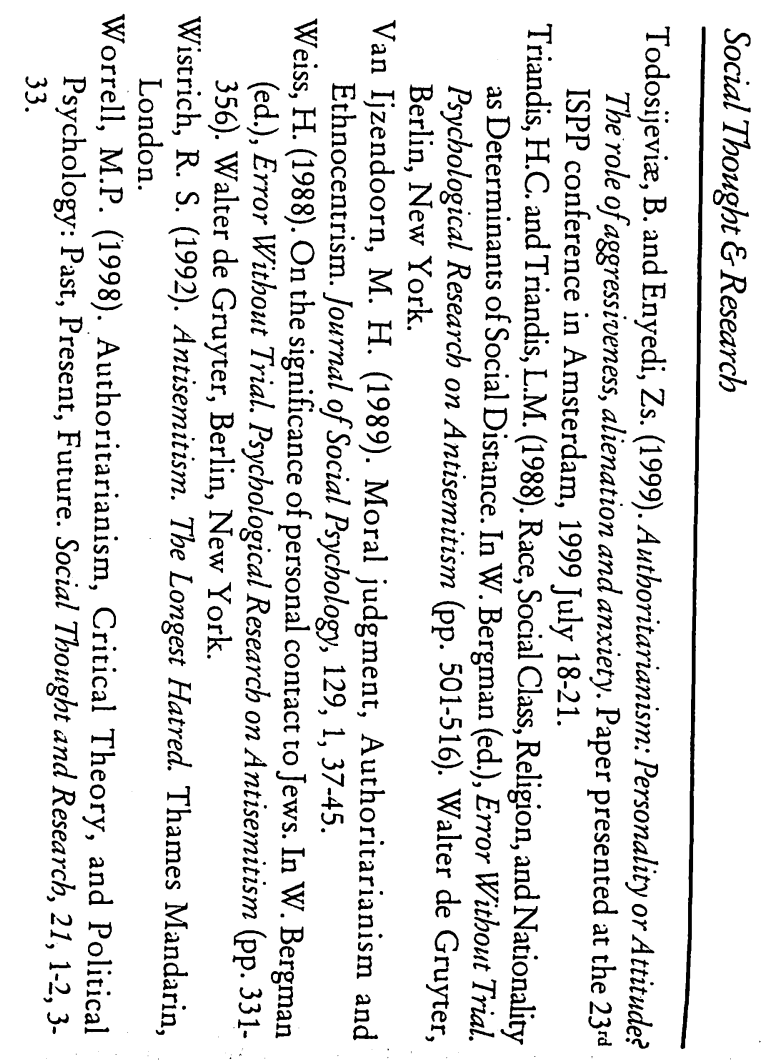

Table 1 Antisemitism scale: 1 st principal component loadings and communalities

\begin{tabular}{|c|c|c|c|c|c|}
\hline \multirow{2}{*}{\multicolumn{2}{|c|}{ Items }} & \multicolumn{2}{|c|}{ Parents } & \multicolumn{2}{|c|}{ Youth } \\
\hline & & Loading & Communality & Loading & Communality \\
\hline A & Marriage between Jews and non Jews does not do good to either & .59 & .35 & .52 & .27 \\
\hline B & There is a secret Jewish cooperation. & .56 & .31 & .44 & .19 \\
\hline $\mathrm{C}$ & Jewish intellectuals keep media and culture under their influence & .59 & .35 & .51 & .26 \\
\hline $\mathrm{D}$ & The deportation and annihilation of Jews in 2nd world war was... & .40 & .16 & .39 & .15 \\
\hline E & What sort of a person one is does not depend on if he is Jewish & .32 & .10 & .43 & .18 \\
\hline $\mathrm{F}$ & In certain professions the number of Jews should be limited & .65 & .42 & 67 & .45 \\
\hline G & Jews are often charged with ridiculous things & .36 & .13 & .43 & .18 \\
\hline $\mathrm{H}$ & Jews profited the most from the system change & .71 & .50 & .48 & .23 \\
\hline I & It would be better if Jews lived in their own state, Israel & .68 & .46 & .70 & .49 \\
\hline $\mathrm{J}$ & One's fortune should not depend on his origin & .30 & .09 & .51 & .26 \\
\hline $\mathrm{K}$ & It is better to have nothing to do with Jews & .63 & .40 & .70 & .50 \\
\hline $\mathrm{L}$ & Hungarian Jews suffered as much as others & .48 & .23 & .53 & .28 \\
\hline M & I will not tell anyone what I think of Jews & .44 & .19 & .43 & .18 \\
\hline \multicolumn{2}{|r|}{ Percent of explained variance: } & $28.5 \%$ & & $27.8 \%$ & \\
\hline
\end{tabular}

Note: For the purpose of statistical analysis all items are coded in the antisemitic direction. 


\begin{tabular}{|c|c|c|c|c|c|}
\hline & \multirow[b]{2}{*}{ Items (abbreviated versions) } & \multicolumn{2}{|c|}{ Parents } & \multicolumn{2}{|c|}{ Youth } \\
\hline & & Loading & Communality & Loading & Communality \\
\hline A & Healthy normal and honest people do not think of hurting friend or ... & .30 & .09 & .40 & .16 \\
\hline B & We should revenge the offenses to our honesty & .38 & .15 & .42 & .18 \\
\hline $\mathrm{C}$ & The most contemptible are those who do not show respect to & & & & \\
\hline & their parents... & .20 & .04 & .39 & .16 \\
\hline D & The most important virtues a child has to learn are obedience... & .69 & .48 & .49 & .24 \\
\hline E & The young sometimes have rebellious thoughts... & .58 & .34 & .51 & .26 \\
\hline F & There live too many non Hungarians in the country... & & & & \\
\hline G & The young should be encouraged to revise the traditions... & .41 & .17 & .31 & .09 \\
\hline $\mathrm{H}$ & Immoral conditions are due to that parents and teachers & .47 & .22 & .35 & .12 \\
\hline I & Traditional religious principles should be less emphasized... & .15 & .02 & -.00 & .00 \\
\hline Tis & Neighboring countries have territories that should belong to & & & & \\
\hline $\mathrm{K}$ & The country rather needs devoted leaders than laws & .64 & .41 & .40 & .16 \\
\hline $\mathrm{L}$ & Violence is often better than long negotiations & .37 & .14 & .14 & .02 \\
\hline M & Young people need strict determination and regulations.. & .63 & .40 & .47 & .22 \\
\hline $\mathrm{N}$ & Most social problems would be solved by getting rid of immoral... & .74 & .55 & .62 & .38 \\
\hline $\mathrm{O}$ & People can be divided into 2 groups: the strong and the weak & .56 & .32 & .46 & .21 \\
\hline $\mathrm{P}$. & One should often say what he thinks & .37 & .14 & .27 & .08 \\
\hline Q & One should be careful not to get a disease... & .57 & .33 & .47 & .22 \\
\hline $\mathrm{R}$ & Most people are not aware that secret conspiracies influence... & .55 & .30 & .42 & .17 \\
\hline
\end{tabular}

$S^{*} \quad$ Life would be better in Hungary if strangers would leave...

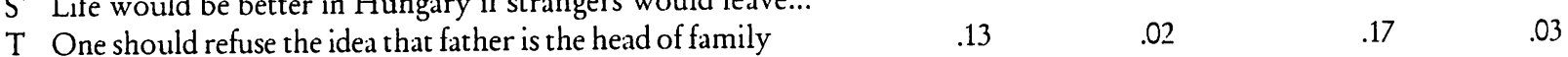

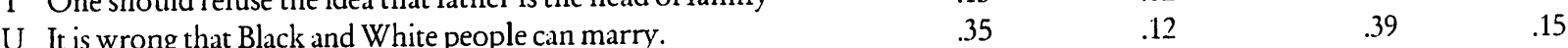

$\mathrm{V}$ Courts are right to condemn drug users...

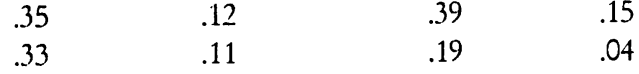

W' It is right that Hungary is the home of all nation who live...

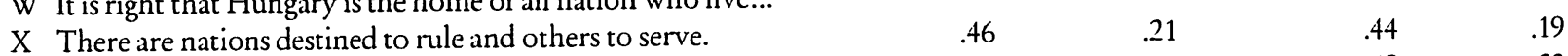

$\begin{array}{lllll}\text { Y None nation is better than the other. } & .48 & .19 & .49 & .23\end{array}$

Explained variance:

$21.8 \% \quad 14.7 \%$

Note: Items F, S, J and W (denoted by superscript star) were not included into the analysis because of direct reference to the 'Hungarian nation', 'strangers' and minorities. Such 'tautological' 'items would probably increase correlation with the antisemitism scale but artificially due to the overlapping content. Therefore, in order to treat the AUT scale as a personality measure it is appropriate to exclude such items. For the purpose of statistical analysis all items are coded in authoritarian direction. 
Table 3 Highest level of completed education of a parent who replied to the questionnaire

\begin{tabular}{lccc}
\hline Value Label & Value & Frequency & Valid Percent \\
\hline Did not go to school & 1 & 1 & .3 \\
Less than 8 years & 2 & 10 & 2.5 \\
8 years (primary school) & 3 & 59 & 14.8 \\
Vocational training & 4 & 113 & 28.3 \\
Finished secondary school & 5 & 126 & 31.5 \\
Finished college & 6 & 54 & 13.5 \\
University & 7 & 37 & 9.3 \\
\hline TOTAL & & 400 & 100.0 \\
\hline
\end{tabular}

Table 4 Highest level of completed education of the spouse of a parent who replied to the questionnaire

\begin{tabular}{lccc}
\hline Value Label & Value & Frequency & Valid Percent \\
\hline Did not go to school & 1 & 0 & .00 \\
Less than 8 years & 2 & 10 & 2.5 \\
8 years (primary school) & 3 & 57 & 14.3 \\
Vocational training & 4 & 69 & 17.3 \\
Finished secondary school & 5 & 115 & 28.8 \\
Finished college & 6 & 54 & 13.5 \\
University & 7 & 20 & 5.0 \\
Missing & & 75 & 18.8 \\
\hline TOTAL & & 400 & 100.0 \\
\hline
\end{tabular}

Table 5 Children's and parents' mean values on the antisemitism principal component (AS and PAS) in relationship to parents' education ${ }^{\mathrm{a}, \mathrm{b}}$

\begin{tabular}{lccc}
\hline Parent's education & $\mathrm{N}$ & $\begin{array}{c}\text { Youth } \\
\text { Antisemitism }\end{array}$ & $\begin{array}{c}\text { Parent's } \\
\text { Antisemitism }\end{array}$ \\
\hline Less than 8 years & 10 & .57 & .55 \\
8 years (primary school) & 56 & -.03 & .19 \\
Vocational training & 111 & .12 & .02 \\
Finished secondary school & 123 & .03 & .04 \\
Finished college & 53 & -.12 & -.22 \\
University & 37 & -.40 & -.45 \\
\hline TOTAL & 390 & -.00 & -.00 \\
\hline
\end{tabular}

a Parents' education refers to the educational level of parents who filled the questionnaire.

b ANOVA tests for marginal relationship of parents' education and both youth and parents' antisemitism are statistically significant $(p<.05)$. 